9. Miroshnikov, V.Yu. On computation of the stress-strain state of a space weakened by a system of parallel circular cylindrical cavities with different boundary conditions [Text] / V. Yu. Miroshnikov//4th International Conference Science and Practice: a New Level of Integration in the Modern World. Conf. Proceedings. Scope Academic House. - Sheffield, UK. 2017. - P. 77-83.

Надійшла до редколегії 27.05.2017

\author{
Anatoly P.Lukisha \\ Institute of Geotechnical Mechanics of the National Academy of Sciences of Ukraine
}

\title{
RECALCULATION METHOD OF THE CHARACTERISTICS OF STRAIGHT-FLOW TUBULAR POROUS STEAM GENERATORS FROM BOUNDARY CONDITIONS OF THE SECOND KIND FOR BOUNDARY CONDITIONS OF THE THIRD KIND
}

The article is devoted to the development of a method for recalculating the thermo-hydraulic characteristics of porous straight-through steam-generating channels from boundary conditions of the second kind to boundary conditions of the third kind. The need for the development of such recalculation procedure is due to the presence in the literature of calculated dependences describing the heat transfer during evaporation of the coolant in porous channel for boundary conditions of the second kind, while the practical plan problems are often conditioned by other boundary conditions, in particular boundary conditions of the third kind. The ultimate goal of the recalculation method was to create a program for calculating the thermo-hydraulic efficiency of porous straight-through steam generators. The proposed recalculation technique makes it possible to calculate, in the porous straightthrough steam generators, for boundary conditions of the third kind, such thermal-hydraulic characteristics as the length of the channel required for complete evaporation of the heat carrier; the power required to pumping the coolant in this case, and the total amount of heat transferred to the heat carrier during evaporation. To describe the calculation of the heat transfer during the evaporation of two-phase flows in porous materials, the experimental dependence obtained by I.V. Kalmykov, characterizing the intensity of volumetric intraporous heat exchange, depending on the regime parameters of the flow, was used. This universal experimental dependence is suitable for various types of porous materials. For calculating the hydraulic characteristics of a evaporating two-phase vaporliquid flow in a porous high thermo-conducting material was used adapted by Yu.A. Zeygarnik and I.V. Kalmykov experimental dependence that was founded on the Lockhart-Martinelli method for calculating the hydro-resistance of vapor-gas flows in porous media. The technique presented in the article makes it possible to calculate the thermal-hydraulic characteristics of porous straight-flow porous steam generators for boundary conditions of the third kind.

Keywords: porous straight-through steam generators, recalculation of thermo-hydraulic characteristics from boundary conditions of the second kind to boundary conditions of the third kind.

Стаття присвячена розробці методу перерахунку теплогідравлічних характеристик пористих прямоточних парогенеруючих каналів з граничних умов другого роду для граничних умов третього роду. Необхідність розробки даної методики обумовлена наявністю в літературі розрахункових залежностей, що описують теплообмін при випаровуванні теплоносія в порстих каналах для граничних умов другого роду, в той час, як завдання практичного плану часто обумовлені іншими граничними умовами, зокрема, граничними умовами третього роду. Остаточною метою методики перерахунку було створення програми по обчисленню теплогідравлічної ефективності пористих прямоточних парогенераторів. Запропонована методика перерахунку дозволяс обчислювати в прямоточних пористих парогенераторах для

(C) Lukisha Anatoly P., 2018 
граничних умов третього роду такі теплогідравлічні характеристики, як довжина каналу, необхідна для повного випаровування теплоносія; потужність, необхідна для прокачування теплоносія в цьому випадку і загальна кількість тепла, що передається теплоносію в процесі випаровування потоку. Для опису розрахунку теплообміну при випаровуванні двофазних потоків в пористому середовищі використовувалася отримана I. B. Калмиковим експериментальна залежність, що підходить для різних типів пористих матеріалів і котра характеризує інтенсивність об'смного внутрішньопористого теплообміну в залежності від режимних параметрів потоку. Для розрахунку гідравлічних характеристик двохфазного парорідинного потоку, що випаровусться в пористому високотеплопровідному матеріалі, використовувалася адаптована Ю.А. Зейгарником і І.В. Калмиковим методика ЛоккартаМартінеллі для розрахунку гідроопору парогазових потоків в пористих середовищах. Наведена в статті методика дозволяє проводити розрахунок теплогідравлічних характеристик прямоточних пористих парогенераторів для граничних умов третього роду.

Ключові слова: прямоточні пористі парогенератори, перерахунок теплогідравлічних характеристик з граничних умов другого роду на граничні умови третього роду.

Статья посвящена разработке метода пересчёта теплогидравлических характеристик пористых прямоточных парогенерирующих каналов с граничных условий второго рода на граничные условия третьего рода. Необходимость разработки данной методики обусловлена наличием в литературе расчётных зависимостей, описывающих теплообмен при испарении теплоносителя в порстых каналах для граничных условий второго рода, в то время, как задачи практического плана часто обусловлены другими граничными условиями, в частности, граничными условиями третьего рода. Конечной целью методики пересчёта являлось создание программы по вычислению теплогидравлической эффективности пористых прямоточных парогенераторов. Предлагаемая методика пересчёта позволяет вычислять в прямоточных пористых парогенераторах для граничных условий третьего рода такие теплогдравлические характеристики, как длина канала, необходимая для полного испарения теплоностеля; мощность, необходимая для прокачки теплоносителя в этом случае и полное количество тепла, передаваемое теплоносителю в процессе испарения. Для описния расчёта теплообмена при испарении двухфазных потоков в пористых материалах использовалась полученная И. В. Калмыковым унверсальная экспериментальная зависимость, подходящая для различных видов пористых матерлов, которая характеризует интенсивность объёмного внутрипористого теплообмена в зависимости от режимных параметров потока. Для расчёта гидравлических характеристик испаряющегося в пористом высокотеплопроводном материале двухфазного парожидкостного потока использовалась адаптированная Ю.А. Зейгарником и И.В. Калмыковым методика Локкарта-Мартинелли для расчёта гидросопротивления парогазовых потоков в пористых средах. Приведенная в статье методика позволяет проводить расчёт теплогидравлических характеристик прямоточных пористых парогенераторов для граничных условий третьего рода.

Ключевые слова: прямоточные пористые парогенераторы, пересчёт теплогидравлических характеристик с граничных условий второго рода на граничные условия третьегого рода.

Introduction. The actual problem of creating various types of heat engineering systems and energy complexes is the increasing of their work efficiency. One of the technical solutions in this direction is the use of porous steam generating channels as part of termal-regulation systems, which use evaporation-condensation phase transitions in their thermodynamic cycle. At the same time, in the course of the design development of such systems, the thermal-hydraulic calculation of the evaporation section is of great importance. The purpose of this calculation is to determination the length of the channel necessary for complete evaporation of the coolant, the power expended for pumping of the evaporating heat carrier and the amount of heat necessary for evaporation of the coolant. In addition, it is of considerable interest to search for calculating -constructive parameters of porous steam generators, at which use it is possible to obtain energy superiority in comparison with smooth-wall steam generators. This gain can be obtained only under boundary conditions of the first or third kind. In the case of boundary conditions of the second kind, according to the law of conservation of energy, at the same 
heat fluxes on the surface of the porous and smooth-walled channels, it is necessary the same length of these channels for evaporation of the same amount of liquid. Taking into account that the hydro resistance of porous channels is higher than the hydro resistance of the smooth-walled channels, it is impossible to obtain an energy gain in this case. Taking into account the above, consider the technique for calculating the characteristics of porous cylindrical straight-flow steam-generating channels for more general case of the boundary conditions of the third kind in comparison with the boundary conditions of the first kind. Let's cause a brief list of calculation formulas describing heat exchange and hydrodynamics in a zone of vaporization of porous cylindrical straight-flow steam generators.

1. Calculation of heat transfer in the movement of two-phase flow in porous materials. The problem of experimental study of heat transfer at moving steam mixture through porous media addressed in dissertation of I. V. Kalmykov [1]. Based on the generalization of experimental data the author has received the following generalized relationship characterizing heat exchange when moving steam-water mixture through porous media

$$
h_{V} / h_{V L O}=1+810 x \sqrt{(\rho v)_{0} \frac{\nu}{\sigma} \cdot \frac{1-x}{x}},
$$

where $h_{V}$ - volumetric heat exchange coefficient at motion of two-phase vapor-liquid flow through the porous material, $W / m^{3} K ; h_{V L O}$ - volumetric heat exchange coefficient inside of the porous material at moving of the liquid at a rate equal to the total rate of the mixture (the amount of heat absorbed by the fluid per unit time per unit volume of the porous body), $W / m^{3} K ;(\rho w)_{0}=\dot{m} / F c$.s. - filtration rate of the mixture (mass flow rate, $\mathrm{kg} / \mathrm{m}^{2} s ; \dot{m}$ - full mass flow rate of mixture, $\mathrm{kg} / \mathrm{s} ; F_{c s}=\pi d^{2} / 4$ - cross-sectional area of the channel, $m^{2} ; v^{\prime}$ - coefficient of cinematic viscosity of the fluid on the saturation line, $\mathrm{m}^{2} / \mathrm{s}$; $\sigma$ - coefficient of surface tension of the liquid, $N / m ; x$ - mass content of steam in the flow.

To find value of $h_{V L O}$ was used recommended by A.G. Kostornov in V.M. Poljaev [2] relationship to calculate the heat transfer inside the porous metal-fiber material when moving through a single-phase coolant:

$$
N u_{V}=0,007 R e^{1,2}
$$

where $N u_{V}=h_{V}(\beta / \alpha)^{2} \lambda_{l}, \quad \operatorname{Re}=\frac{(\rho w)_{0}(\beta / \alpha)}{\mu_{l}}, \alpha$ and $\beta-$ viscous and inertial coefficients of resistance of porous material; index $l$ refers to the parameters of fluid.

As seen from the expression (1) it does not include in explicit form of the porous structure characteristic parameters, such as particle size, or flow resistance coefficients $\alpha$ and $\beta$. This makes it possible to use these expressions for virtually any porous materials.

In calculating the specific heat flux, which is passed to the coolant during evaporation in a porous cylindrical channel, we used the expression obtained in [3]

$$
q=\left(\lambda_{\text {por }} h_{V}\right)^{1 / 2} \frac{I_{1}(\gamma)}{I_{0}(\gamma)} \vartheta(1),
$$

where $I_{0}(\gamma)$ and $I_{l}(\gamma)$ - modified Bessel functions of the first kind of zero and first order, respectively; $\lambda_{\text {por }}$ - coefficient of thermal conductivity of the porous material. For it's 
calculation the material of the frame of the wick, the thermal conductivity of liquid and vapor at saturation line have to be taken into consideration; $h_{V}$ - the intensity of the volume of the intraporous heat transfer; $\gamma^{2}=\frac{h_{V}(d / 2)^{2}}{\lambda}-$ parameter characterizing the intensity of the intraporous heat exchange; $d$-diameter of channel; $\vartheta=T-t_{s}$, where $T-$ the temperature of the porous structure, $t_{s}$ - the coolant temperature at the saturation line; $\vartheta(1)=T_{w}-t_{s},-$ temperature difference of the porous frame and on the cooler inner surface of the wall.

According to [3] at boundary conditions of the third kind for value $\vartheta(1)=T_{w}-t_{s}$ could be written the following expression:

$$
\vartheta(1)=\left(\frac{I_{0}(\gamma) \cdot \vartheta_{\infty}}{I_{0}(\gamma)+\frac{\gamma}{B i_{p o r}} \cdot I_{1}(\gamma)}\right),
$$

where

$$
\vartheta_{\infty}=t_{\infty}-t_{s} ; \quad B i_{\text {por }}=\frac{\kappa^{\prime}(d / 2)}{\lambda_{\text {por }}} .
$$

Substituting the value $\vartheta(1)$ from (4) in (3), we obtain the following expression for the specific heat flux, which is passed to the heat carrier in the porous cylindrical channel at boundary conditions of the third kind:

$$
q=(\lambda h)^{1 / 2} \cdot \frac{I_{1}(\gamma) \cdot \vartheta_{\infty}}{I_{0}(\gamma)+\frac{\gamma}{B i \text { por }} \cdot I_{1}(\gamma)} .
$$

If to look on the value of the criterion of Bio from formula (6), written for the solution of the problem in a porous channel, we can see that it is bound by the following relationships with the criterion of Bio, written to solve the problem in the smooth-walled channel.

$$
\begin{gathered}
B i_{s m}=\frac{\kappa^{\prime} \cdot d}{\lambda_{\ell}} ; \\
B i_{p o r}=\frac{\kappa^{\prime}(d / 2)}{\lambda_{p o r}} ; \\
B i_{p o r}=B i_{s m} \frac{\lambda_{\ell}}{2 \lambda_{p o r}},
\end{gathered}
$$

where $\kappa^{\prime}$ - local heat transfer coefficient from the internal surface of a wall to the environment; $\lambda_{l}$ - coefficient of thermal conductivity of a liquid.

For the parameter $\kappa$ ' we can write the following expression:

$$
\frac{1}{\kappa}=\frac{1}{\alpha}+\frac{1}{\kappa^{\prime}},
$$

where $\kappa$ - the local heat transfer coefficient from the liquid flowing in the pipe to the environment; $\alpha$ - local heat transfer coefficient from the liquid flowing in the pipe to the internal surface of a wall. 
For a round pipe there is an expression [4]:

$$
\frac{1}{\kappa^{\prime}}=\frac{d}{2 \lambda_{w}} \ln \frac{d_{1}}{d}+\frac{d}{\alpha_{1} d_{1}},
$$

where $\alpha_{1}-$ is heat-transfer coefficient from the outside surface of a tube to the environment; $d, d_{1}$ - are inner and outer pipe diameters; $\lambda_{w}-$ is the coefficient of thermal conductivity of the wall material.

2. Calculation of hydraulic resistance in porous channels with high heat conductivity at two-phase vapour-liquid motion of heat carrying agent. Calculation of hydraulic resistance in porous channels with high heat conductivity at two-phase vapour-liquid motion of heat carrying agent will be performed as the method similar to Lockhart-Martinelli's method [5]. According to this method, which Yu. A. Zeigarnik and I.V. Kalmykov applied to the motion of two-phase vapour-liquid adiabatic flows in porous media [6], the calculation of the frictional resistance of adiabatic two-phase mixture in porous channels is performed as the formulas:

$$
\left(\frac{\Delta P}{\ell}\right)_{t w \cdot p h . p o r .}=(\Delta P / \ell)_{L} \cdot \Phi_{L}^{2},
$$

or

$$
\left(\frac{\Delta P}{\ell}\right)_{\text {tw.ph. por. }}=(\Delta P / \ell)_{G} \cdot \Phi_{G}^{2},
$$

where $(\Delta P / \ell)_{L}$ and $(\Delta P / \ell)_{G}$ are pressure drops at the flow through a porous structure of a liquid phase only in the quantity that the mixture contains, or of steam phase only. These values are calculated as the equation (14), in which corresponding mass filtration velocities of each phase are used as mass filtration velocities $\rho w=G$ :

$$
\frac{-d P}{d Z}=\alpha \mu v G+\beta v G^{2},
$$

where $\alpha$ and $\beta$-are inertial and viscosity coefficients of a porous material resistance; $\mu$ and $v$ are dynamic viscosity coefficient and specific volume of liquid; $G$ is mass flow rate of liquid through a porous material.

According to Lockart and Martinelli [5], parameters $\Phi_{L}$ and $\Phi_{G}$ are the function of Martinelli parameter $X=\sqrt{(\Delta P / \ell)_{L} /(\Delta P / \ell)_{G}}$. The following formula can be written for $X^{2}$ parameter [6] :

$$
X^{2}=\left(\frac{1-x}{x}\right)\left(\frac{\mu^{\prime}}{\mu^{\prime \prime}}\right)\left(\frac{\rho^{\prime \prime}}{\rho^{\prime}}\right) \frac{1+(\beta / \alpha)[G(1-x)] / \mu^{\prime}}{1+(\beta / \alpha)[G \cdot x] / \mu^{\prime \prime}}=\left(\frac{1-x}{x}\right)\left(\frac{\mu^{\prime}}{\mu^{\prime \prime}}\right)\left(\frac{\rho^{\prime \prime}}{\rho^{\prime}}\right) \frac{1+R e^{\prime}}{1+R e^{\prime \prime}} .
$$

The connection between parameter $X$ and $\Phi_{L}$ and $\Phi_{G}$ can be expressed analytically [7]:

$$
\begin{gathered}
\Phi_{L}^{2}=1+C / X+1 / X^{2}, \\
\Phi_{G}^{2}=1+C X+X^{2} .
\end{gathered}
$$

After processing experimental data, Yu. A. Zeigarnik and I.V. Kalmykov in [6] concluded that coefficient $C$ is the function of mass filtration velocity $(\rho w)_{0}=G$, physical 
characteristics $\left(\rho^{\prime}\right.$ and $\left.\mu^{\prime}\right)$ and hydraulic characteristics of porous structure (coefficients $\alpha$ and $\beta$ ):

$$
C=4,0\left(\frac{\beta / \alpha}{G} \cdot \frac{\rho^{\prime}}{\mu^{\prime}}\right)^{0,4} .
$$

3. Calculation scheme for computation of thermophysical parameters of cylindrical porous channel at motion through it of two-phase evaporating flow under boundary conditions of the third kind. To obtain a scheme for calculating of the thermo-physical parameters of a cylindrical porous channel, it is necessary at the inlet to the channel with a diameter $d$ to set the flow parameters on the saturation line temperature $T_{s 0}$ and pressure $P_{s 0}$. Also at the channel entrance the Reynolds number $R e_{0}$ (mass flow rate $\dot{m}, \mathrm{~kg} / \mathrm{s}$ ) is set. On the channel surface, the ambient temperature $\mathrm{T}_{1 \infty}$ and the law of heat exchange between the channel wall and the environment (Bi criterion) are set. Wherein, the temperature drop across the channel wall thickness is not taken into account, since it is assumed that the wall thickness is rather small.

Due to the fact that for beginning of calculations of thermal characteristics in a smooth-wall steam-generating channel (formulas (1) - (6)), it is necessary to know the value of the vapour content, then we assume that at the channel entrance this value is equal to $0,001\left(x_{0}=0,001\right)$. Schematically, the calculation scheme of computation is shown in Fig. 1.

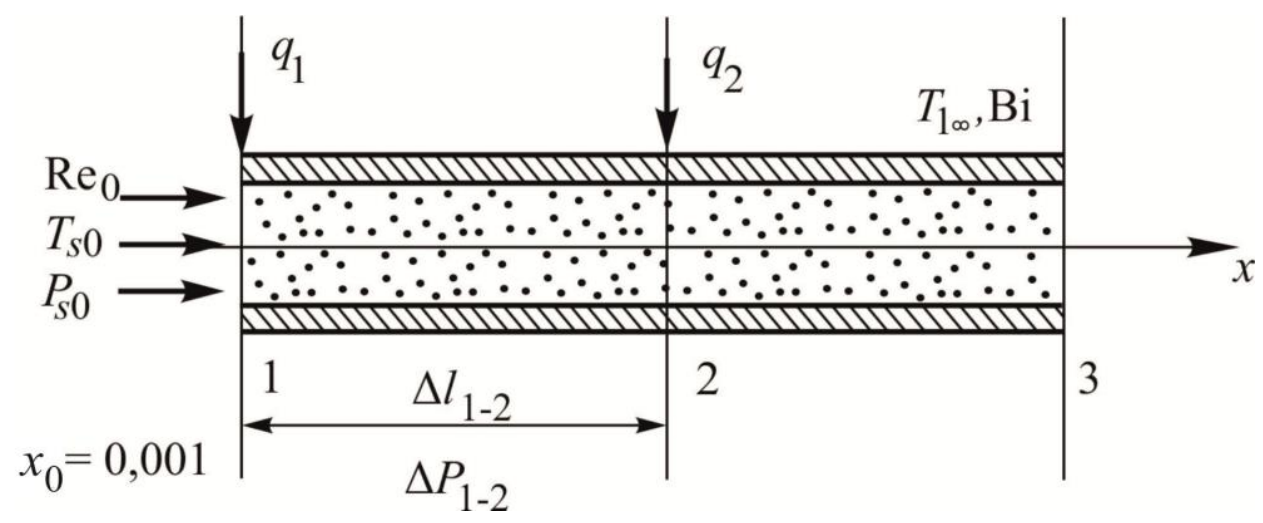

Fig. 1. Calculation scheme of computation of thermal characteristics in a steam generating porous channel

Since the calculated values of the heat flux and the heat transfer coefficient in formula (1) are written for boundary conditions of the second kind, we stake out the channel into small sections $\Delta l$, within which we will assume that the value of the heat flux is constant. In the course of the calculations, the value of $\Delta l$ was assumed equal to $0,01 \mathrm{~mm}$. The parameter characterizing the end of one section and the beginning of the second section is the boundary vapour content. Within these sections, the calculation of the thermo-physical characteristics of the channel was carried out by the method of successive approximations. 
In the first step of the calculations in section 1 (input section) (fig. 1), calculate the specific heat flux

$$
q_{1}^{(1)}=f\left(T_{1 \infty}, B i, T_{s 0}, P_{s 0}, x_{0}, R e_{0}, d\right),
$$

with using of equation (1) and equation (2).

Next, we calculate the total amount of heat, which is transferred to the evaporating heat carrier between sections 1 and 2 by formula

where

$$
Q_{1-2}^{(1)}=q_{1} \cdot F_{\text {lat.surf.1-2 }},
$$

After that, we find the increment of the vapour content in the section 1-2:

$$
\Delta x_{1-2}^{(1)}=\frac{Q_{1-2}}{\dot{m} \cdot r\left(1-x_{0}\right)}
$$

and the value of the vapor content in section 2 in the first step of the iteration:

$$
x_{2}^{(1)}=x_{o}+\Delta x_{1-2},
$$

where $\dot{m}$ - the total mass flow rate of the heat carrier through the pipe (channel), $\mathrm{kg} / \mathrm{s}$; $r$ - is the heat of vaporization, $\mathrm{J} / \mathrm{kg} ; x$ - is the mass steam content of flow.

Note, that the lower indices in the above expressions refer to the cross section number of channel, and the upper indices refer to the sequence number of the iteration.

Knowing the values of $x_{o}$ and $x_{2}^{(1)}$, we find the average value of the vapour content between cross sections 1 and 2 in the first step of the iteration

$$
x_{1-2 \text { av. }}^{(1)}=\left(x_{o}+x_{2}^{(1)}\right) / 2 .
$$

Based on the thermo-physical properties of the liquid in the inlet cross section of the pipe, the calculated vapor content, the relative length of the section $x_{1-2 a v}^{(1)}$, the relative length of the section $\Delta \xi=\Delta \ell / d$, the Reynolds number at the entrance of the channel $R e_{o}$ and the diameter of the channel $\mathrm{d}$, we calculate the pressure drop in section 1-2 (formulas (7) $-(14))$

$$
\Delta P_{1-2}^{(1)}=f\left(\Delta \xi, x_{1-2 \text { av. }}^{(1)}, \operatorname{Re}_{o}, d\right)
$$

and the value of saturation pressure in the cross section 2 :

$$
P_{s 2}^{(1)}=P_{s o}-\Delta P_{1-2}^{(1)} \text {. }
$$

Using the pressure value $P_{s 2}^{(1)}$, we find the temperature value on the saturation line in cross section 2 in the first step of the iteration

$$
T_{s 2}^{(1)}=f\left(P_{s 2}^{(1)}\right) .
$$

The values of the thermo-physical properties of liquid and vapor on the saturation line are usually found by interpolation between discrete points. In the course of numerical realization of this technique, interpolation was carried out using the Lagrange interpolation formula. The discrete values of the thermo-physical properties of liquid and vapour were taken from tables [8]. 
The average temperature of the liquid in the section 1-2 is calculated from the temperature values $T_{s o}$ and $T_{s 2}^{(1)}$

$$
T_{s 1-2 a \mathrm{v}}^{(1)}=\frac{T_{s o}+T_{s 2}^{1}}{2} .
$$

By the value of this temperature, using the Lagrange interpolation formula, the average value of the saturation pressure in the $1-2$ section is calculated:

$$
P_{s 1-2 a v}^{(1)}=f\left(T_{s 1-2 a v}^{(1)}\right) \text {. }
$$

Further, proceeding from the previously calculated values $x_{2}^{(1)}, P_{s 2}^{(1)}, T_{s 2}^{(1)}$ (formulas (23), (26), (27)), we calculate the value of the specific heat flux in cross section 2 in the first step of the iteration.

$$
q_{1}^{(1)}=f\left(\mathrm{~T}_{1 \infty,}, B i, T_{s 2}^{(1)}, P_{s 2}^{(1)}, x_{2}^{(1)}, R e_{\mathrm{o}}, d\right) .
$$

Then we calculate the value of the average specific heat flux in the section 1-2 in the first step of the iteration, assuming this value is constant within the section 1-2

$$
q_{1-2 a v}^{(1)}=\frac{q_{1}^{(1)}+q_{2}^{(1)}}{2} .
$$

After this, we go to the second step of the iteration and again calculate the value of the total amount of heat which is transferred to the evaporating heat carrier between sections 1 and 2

$$
Q_{1-2}^{(1)}=q_{1-2 \text { av }}^{(1)} \pi d \Delta \ell_{1-2} \text {. }
$$

Further, according to the above scheme, we calculate the next set of thermohydraulic characteristics of the evaporating flow in section 1-2 in the second step of the iteration.

$$
\Delta x_{1-2 a v}^{(1)}=\frac{Q_{1-2}^{(2)}}{\dot{m} \cdot r(1-x)} .
$$

We note that at this step of the iteration the value of the heat of evaporation $r$ in formula (33) is calculated from the mean values of the saturation temperature $T_{s 1-2 \text { av }}^{(1)}$ and the saturation pressure $P_{s 1-2 a v}^{(1)}$ obtained in the previous iteration step (formulas (28) and (29), respectively).

$$
\begin{gathered}
x_{2}^{(2)}=x_{o}+\Delta x_{1-2 a v}^{(2)}, \\
x_{1-2 a v}^{(2)}=\frac{x_{o}+x_{2}^{(2)}}{2}, \\
\Delta P_{1-2}^{(2)}=f\left(\Delta \xi, x_{1-2 a v}^{(2)}, R e_{o}, d\right), \\
P_{s 2}^{(2)}=P_{s o}-\Delta P_{1-2}^{(2)}, \\
T_{s 2}^{(2)}=f\left(P_{s 2}^{(2)}\right),
\end{gathered}
$$




$$
\begin{gathered}
T_{s 1-2 a v}^{(2)}=\frac{T_{s o}+T_{s 2}^{(2)}}{2}, \\
P_{s 1-2 a v}^{(2)}=f\left(T_{s 1-2 a v}^{(2)}\right), \\
q_{2}^{(2)}=f\left(T_{100}, B i, T_{s 2}^{(2)}, P_{s 2}^{(2)}, x_{2}^{(2)}, R e_{o}, d\right), \\
q_{1-2 a v}^{(2)}=\frac{q_{1}+q_{2}^{(2)}}{2} .
\end{gathered}
$$

Having the values of $q_{1-2}^{(1)}$ and $q_{1-2}^{(2)}$ av , calculated at the first and second step of the iteration, we compare them each with other and calculate the relative magnitude of the discrepancy between these quantities:

$$
\Delta C=\frac{q_{1-2 a v}^{(2)}-q_{1-2 a v}^{(1)}}{q_{1-2 a v}^{(2)}} \cdot 100 \% .
$$

If the value of $\Delta C$ is greater than $1 \%$, then the average value of the specific heat flux in the distance between the cross sections 1-2 obtained in the second iteration step $\left(q_{1-2 \text { av }}^{(2)}\right)$ is substituted into the formula (30) instead of the same value that was obtained in the first step of the iteration $\left(q_{1-2 \text { av }}^{(1)}\right)$ and calculations of the thermo-hydraulic values, starting with formula (32) to formula (40) are carried out again. In such way the third step of the iteration (the third successive approximation) is organized. The calculation of thermal-hydraulic characteristics by the method of the successive approximations in the initial section 1-2 continues until the condition $\Delta C \leq 1 \%$ is satisfied. After this condition is fulfilled, the final value of the total amount of heat is calculated on the interval between cross sections 1 and 2 :

$$
Q_{1-2 \text { final. }}^{(I)}=q_{1-2 \text { final. }}^{(i)} \pi d \Delta \ell .
$$

After the condition $\Delta C \leq 1 \%$ has been fulfilled, the hydraulic power required to pump the coolant in the $1-2$ section is calculated too:

$$
N_{1-2 \text { final. }}^{(I)}=\Delta P_{1-2 \text { final. }}^{(i)} \cdot \frac{\dot{m}}{\rho_{1-2}^{(i)}},
$$

where $\dot{m}=\frac{R e_{0} \mu_{\mathrm{o}} \pi d}{4}-$ is the total mass flow rate of the heat carrier through the pipe (channel), $\mathrm{kg} / \mathrm{s} ; \operatorname{Re}_{0}$ and $\mu_{0}$ are the Reynolds number and the dynamic viscosity of the fluid in the inlet cross section of the channel; $\rho_{1-2}^{(i)}-$ the density of the liquid, calculated from the value of temperature $T_{s 1-2}^{(i)}$.

After calculating of the values $Q_{1-2 \text { final. }}^{(I)}$ and $N_{1-2 \text { find. }}^{(I)}$, these values as well as the value $\Delta \ell_{1-2}=$ const are entered in the database for their subsequent use when finding the total amount of heat which is transferred to the evaporating heat carrier, the total 
power expended for pumping the cooler and the total length of the channel at which the evaporation of the coolant is complete.

After the calculation of the thermo-hydraulic parameters of the evaporating flow in the section 1-2 was completed, the calculated values in cross section 2 were taken as the initial values for the next interval 2-3 (fig. 1) and the calculations in this section were carried out according to the calculation scheme in the interval 1-2. After the complete of calculations in section $2-3$, the summation of the values $Q_{1-2 \text { final. }}^{(I)}+Q_{2-3 \text { final.; }}^{(I I)}$; $N_{1-2 \text { final. }}^{(I)}+N_{2-3 \text { final. }}^{(I)} ; \Delta \ell_{1-2}+\Delta \ell_{2-3}$, the calculations were transferred to the interval $3-4$, etc.

The calculation should be carried out until the value of the vapor content with an accuracy of $1 \%$ becomes equal to the value $x=1$.

Conclusion. The above procedure allows to do the recalculation of the thermohydraulic characteristics of straight-flow porous steam generators from boundary conditions of the second kind to boundary conditions of the third kind. This calculation method was created with the purpose of subsequent calculation of the thermo-hydraulic efficiency of straight-through cylindrical steam generators and was implemented in the form of a computational program.

\section{Bibliographic references}

1. Kalmykov, I.V. Heat transfer and hydrodynamics at motion of the steam-liquid flow in porous media [Текст] : The dissertation on competition for the degree of candidate of technical sciences, /I.V. Kalmykov. - Moscow, 1987. - 224 p. (rus.)

2. Poljaev, V.M. Hydrodynamics and heat transfer in porous design elements of aircraft [Текст] / V.M. Poljaev, V.A. Majorov, L.L. Vasiliev. - Moscow: Mashinostroenije Press, 1988. 168 p. (rus.)

3. Lukisha, A.P. Heat exchange at evaporating of flow in the cylindrical porous channel [Текст] / A.P. Lukisha // Visnyk Dnipropetrvskogo universitety. Ser.: mechanica. Dnipropetrovsk, 2014. - Vol. 22. - № 3. - Iss. 16. - P. 107-114. (rus.)

4. Petuhov, B.S. Heat transfer and resistance at laminar flow of a liquid in pipes[Текст] / B.S. Petuhov. - Moscow: Energija Press, 1967. - 411 p.(rus.).

5. Lockart, R.W. Proposed correlation of data for isothermal two-phase, two-component flow in pipes [Текст] / R.W. Lockart, R.C. Martinelli // Chemical Engineering Progress. - 1949. Vol. 45(1). - P. 39-48.

6. Zeigarnik, Yu. A. Experimental study of the hydraulic resistance of porous structures at adiabatic motion steam-water mixture [Текст] / Yu.A. Zeigarnik, I.V. Kalmykov // Teplofizika vysokih temperature. - 1985. - Vol. 23. - № 5. - P. 934-940.(rus.)

7. Chisholm, D. Prediction of pressure gradient in pipeline system during two-phase flow [Текст] / D. Chisholm, L.A. Sutherland // Proc. Inst. Mech. Engrs, 1969. - Vol. 184. - Iss. 3 P. 24-32.

8. Vargaftik, N. B. Handbook on thermophysical properties of gases and liquids / N. B. Vargaftik. - M.: Nauka, 1972. - 720 p.(rus.)

Надійшла до редколегії 12.02.2017 